\title{
OTU accumulation curves
}

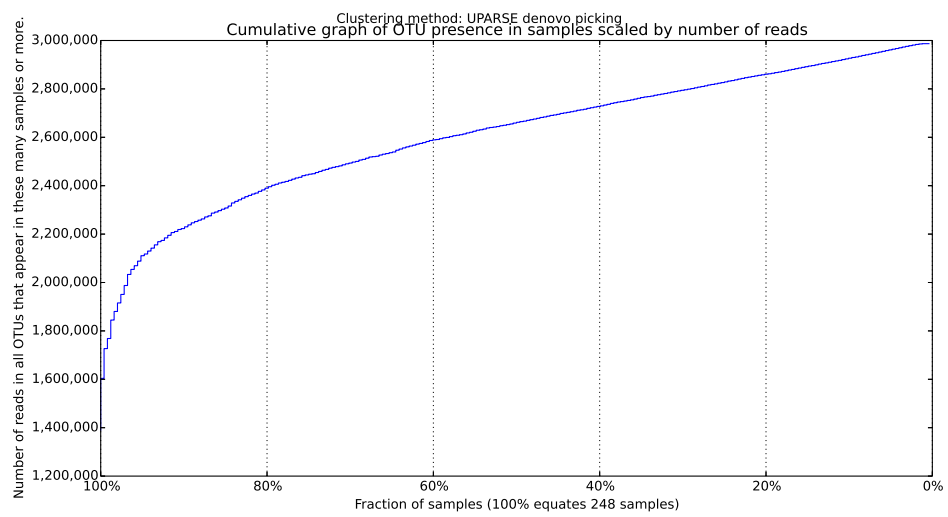

(a) UPARSE clustering method

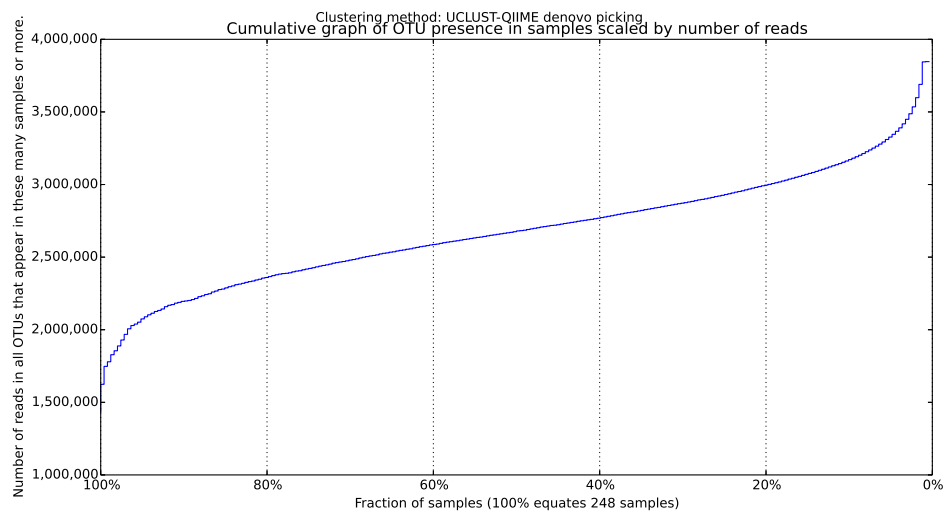

(b) UCLUST clustering method

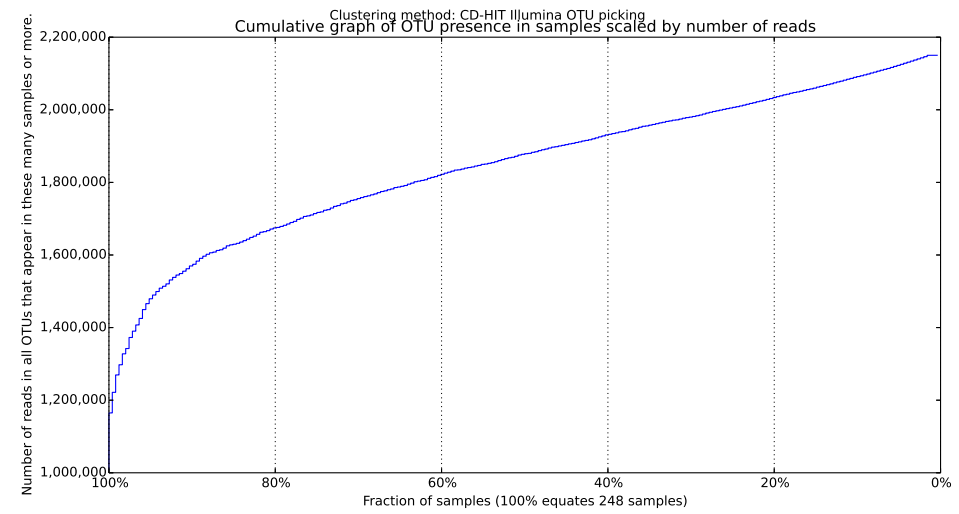

(c) CD-HIT-OTU clustering method 